\title{
Biochar and zeolites did not improve phosphorus uptake or crop productivity in a field trial performed in an irrigated intensive farming system
}

\author{
Margarida Arrobas $^{1} \quad$ ～João V. Decker ${ }^{2} \quad$ Bruna L. Feix ${ }^{3} \quad$ Wilson I. Godoy ${ }^{2}$ | \\ Carlos A. Casali $^{3}$ | Carlos M. Correia ${ }^{4}$ | Manuel Ângelo Rodrigues ${ }^{1}$ (iD
}

${ }^{1}$ Centro de Investigação de Montanha (CIMO), Instituto Politécnico de Bragança/

Campus de Sta Apolónia, Bragança,

Portugal

${ }^{2}$ Universidade Tecnológica Federal do Paraná/Campus Pato Branco, Paraná, Brazil

${ }^{3}$ Universidade Tecnológica Federal do Paraná/Campus Dois Vizinhos, Paraná, Brazil

${ }^{4}$ Centre for the Research and Technology of Agro-Environmental and Biological Sciences (CITAB), University of Trás-osMontes e Alto Douro, Vila Real, Portugal

\section{Correspondence}

Manuel Ângelo Rodrigues, Centro de Investigação de Montanha (CIMO), Instituto Politécnico de Bragança,

Bragança, Portugal.

Email: angelor@ipb.pt

\section{Funding information}

The authors are grateful to the Foundation for Science and Technology (FCT,

Portugal) and European Regional

Development Fund (ERDF) under

Programme PT2020 for financial support to Centro de Investigação de Montana (CIMO) (UID/AGR/00690/2015) and Centre for the Research and Technology of AgroEnvironmental and Biological Sciences (CITAB) (UIDB/04033/2020).

\begin{abstract}
Soil conditioners, such as biochar and zeolites, may play an important role in agriculture if they increase nutrient use efficiency, in particular, that of phosphorus $(\mathrm{P})$, due to the depletion of phosphate rocks from which P-fertilizers are manufactured. This study report results from a field trial, where maize was grown in summer and oats in winter, and from a pot experiment with maize. In the field, the use of biochar and zeolites, along with an untreated control in combination with various $P$ rates $(0$, 50,100 and $200 \mathrm{~kg} \mathrm{P}_{2} \mathrm{O}_{5} \mathrm{ha}^{-1}$ ), was tested. In the pot experiment, six treatments were included, biochar, zeolites and a non-amended control with and without P application. Soil conditioners did not significantly influence tissue elemental composition or the dry matter (DM) yield of maize and oats in the field trial, nor the DM yield of maize in the pots. In the field trial, average maize DM yields varied from 14.3 to 15.6 $\mathrm{t} \mathrm{ha}^{-1}$ and 11.8 to $13.7 \mathrm{tha}^{-1}$ and average oats DM yields from 2.1 to $2.4 \mathrm{t} \mathrm{ha}^{-1}$ and 3.0 to $3.2 \mathrm{tha}^{-1}$, respectively, in 2018 and 2019 . Biochar only significantly increased total organic carbon $(\mathrm{C})$; and zeolites the levels of potassium $(\mathrm{K})$ in the soil, a result of their initial composition. P application increased DM yield of maize in the second year and oats in the two years of the field trial and also the DM yield of potted maize. In the pots, $\mathrm{P}$ application also influenced the concentration of $\mathrm{P}$ and several other nutrients in plant tissues and increased the labile soil $\mathrm{P}$ fraction. This study showed that the biochar and zeolite soil conditioners applied may not be suitable for shortterm increase of crop production in soil with high agricultural potential and under intensive irrigated farming systems.
\end{abstract}

\section{K E Y W O R D S}

Avena sativa, carbon sequestration, soil conditioners, soil properties, tissue elemental composition, Zea mays

\section{1 | INTRODUCTION}

The shortage of $\mathrm{P}$ in soils limits the productivity of crops in many parts of the world. It is estimated that the availability of $\mathrm{P}$ for plant roots is limited in approximately $2 / 3$ of soils cultivated worldwide, which represents an important constraint on crop production (Li et al., 2016). Phosphate rock is virtually the only raw material for the manufacture of phosphate fertilizers (Kongshaug, 2007). The main source of $\mathrm{P}$ is phosphate sedimentary rocks (phosphate produced from the seabed and bones) but also phosphate magmatic (igneous) rocks. Phosphate rocks 
are mined in approximately 30 countries and phosphate fertilizers manufactured in 26 countries across the world (Kongshaug, 2007).

The use of $\mathrm{P}$ fertilizers in agriculture is currently viewed with some concern, as it is estimated that the phosphate rocks used in the manufacture of $\mathrm{P}$ fertilizers will become depleted during the 21st century (Gilbert, 2009). It is therefore urgent to learn how to manage $P$ rationally in agriculture to preserve this important non-renewable resource (Tian et al., 2020). In addition, only $20 \%$ of the $\mathrm{P}$ used as fertilizer is taken up by plants and recovered in crops (Havlin et al., 2014). In recent years, several materials usually known as soil conditioners or soil improvers, such as biochar and zeolites, have been tested as a means of improving general soil properties and crop yield, but also in particular soil P bioavailability by influencing soil $\mathrm{pH}$ and $\mathrm{P}$ adsorption/desorption equilibrium or altering P solubility by enhancing microbial activities (Bernardi et al., 2010; Gao et al., 2019).

Biochar, a charcoal-like material, can be obtained from a range of biomass feedstock by pyrolysis, hydrothermal carbonization and gasification, among which pyrolysis is the most widely adopted methods due to its relative simplicity (Wang et al., 2020). Biochar has been widely recommended as a soil amendment due to its dual benefits of improving soil quality and enhancing soil C sequestration (Arif et al., 2017; Kavitha et al., 2018; Wei et al., 2020; Yu et al., 2019). In biochar amended plots, the availability of $\mathrm{P}$ to plants is enhanced by anion exchange capacity of biochar and/or by cations that interact with P (Shaaban et al., 2018; Si et al., 2018). Biochar contains amorphous aromatic compounds with heteroatoms in the aromatic rings which play a great role in making the surface of biochar heterogeneous and reactive, which along with the high surface and porosity increase cation and anion exchange capacity (Shaaban et al., 2018) Biochar may also reduce the formation of $\mathrm{P}$ precipitates, either in acid or alkaline soils, and therefore, increase availability of $\mathrm{P}$ to plants (Cui et al., 2011; Zhang et al., 2016). In a meta-analysis performed by Gao et al. (2019), based on 124 peer-reviewed published studies, they found a fairly consistent increase in available $\mathrm{P}$ in agricultural soils following treatment with biochar.

Zeolites are hydrated crystalline aluminosilicate minerals, either of natural occurrence or synthesized from power plant fly ash (Bernardi et al., 2010; Prawiyanto et al., 2018). It is known that zeolites have ion-exchange and adsorption and catalytic properties (Ryakhovskaya \& Gainatulina, 2009). When applied to soils in combination with rock phosphate, zeolites improve $\mathrm{P}$ availability from phosphate rocks, with $\mathrm{Ca}^{2+}$ exchanging onto the zeolite in response to plant uptake of nutrient cations $\left(\mathrm{NH}_{4}^{+}, \mathrm{K}^{+}\right)$enhancing the dissolution of rock phosphate (Pickering et al., 2002). When used in mixtures with organic substrates, it was also found that zeolites increase plant $\mathrm{P}$ nutritional status (Assimakopoulou et al., 2020). Experimental results also indicate that N, P and
$\mathrm{K}$ precharged zeolites are an adequate slow-release nutrient source for plants (Guaya et al., 2020; Liator et al., 2017).

Although beneficial effects on crops have often been observed through the application of biochar or zeolites to soils, in some studies the effect of using these soil conditioners on crop productivity was negligible, non-existent or even negative (Gao et al., 2019; Liator et al., 2017; Wei et al., 2020). In addition, from the farmer's perspective, these materials are production factors with an associated cost. Their use should generate a net income for the farmer, otherwise, it is unrealistic to think that their use will be widely adopted despite potential environmental benefits, due to $\mathrm{C}$ sequestration in the case of biochar, or improved soil properties that can bring long-term benefits to the agro-system. In this study, the effect of applying biochar and zeolites in combination with $\mathrm{P}$ applications in field and pot experiments was studied. The field experiment was carried under a cropping system very common in the region, where forage maize is grown in the summer and oats in the winter. The pot experiment had the objective of obtaining a better assessment of the effect of the treatments by reducing the experimental variability and it was carried out only with maize. The working hypothesis was that the use of biochar and/or zeolites may result in benefits in soil properties, crop nutritional status, $\mathrm{P}$ use efficiency and/or crop productivity which allow these materials to be recommended for use by farmers.

\section{MATERIALS AND METHODS}

\section{$2.1 \quad$ Field trial}

The field experiment was carried out in the experimental farm of Poulão ( $41^{\circ} 47^{\prime} \mathrm{N}$; $6^{\circ} 46^{\prime} \mathrm{W}$; $750 \mathrm{~m}$ a.s.l.) in Bragança, NE Portugal. The plot where the experiment took place is organized as an 8-year rotation, in which 4 years of a double forage maize crop (summer)-oats (winter) is followed by a temporary 4-year pasture. The region benefits from a Mediterranean climate. Annual air temperature and accumulated precipitation are $12.7^{\circ} \mathrm{C}$ and $772.8 \mathrm{~mm}$, respectively. Local data of average monthly temperature and precipitation recorded during the experimental period is presented in Figure 1 . The soil is a loamy (soil separates are $54.1 \%$ sand, $26.2 \%$ silt and $20.7 \%$ clay) Eutric Fluvisol, developed in fluvial deposits (WRB, 2015), with low levels of P. Other soil properties from samples taken when the experiment started are presented in Table 1. Table 1 also contains data on the properties of the soil used in the pot experiment described below.

Two experimental factors were used, soil conditioning (three levels) and P fertilization (four levels). Soil conditioners were biochar, zeolites and a non-treated control (mineral fertilization only). The $\mathrm{P}$ rates were 0 (P0), 50 (P50), 100 
F I G URE 1 Average air monthly temperature and precipitation during the experimental period and data of the climate normal of the region

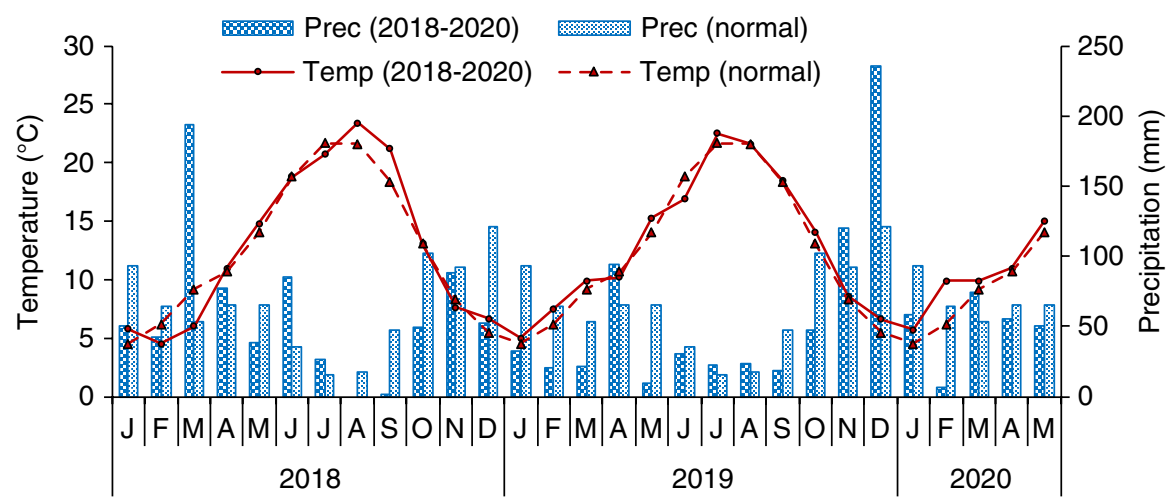

TA B L E 1 Selected soil properties (average \pm standard deviation) from soil samples $(0-20 \mathrm{~cm})$ taken just before the trials started

\begin{tabular}{|c|c|c|}
\hline Soil properties & Pot experiment & Field trial \\
\hline${ }^{1} \mathrm{pH}\left(\mathrm{H}_{2} \mathrm{O}\right)$ & $6.54 \pm 0.11$ & $5.54 \pm 0.06$ \\
\hline${ }^{1} \mathrm{pH}(\mathrm{KCl})$ & $5.31 \pm 0.10$ & $4.64 \pm 0.12$ \\
\hline${ }^{2}$ Organic $\mathrm{C}\left(\mathrm{g} \mathrm{kg}^{-1}\right)$ & $7.08 \pm 0.20$ & $12.71 \pm 0.36$ \\
\hline${ }^{3}$ Total $\mathrm{N}\left(\mathrm{g} \mathrm{kg}^{-1}\right)^{5}$ & $0.81 \pm 0.10$ & $1.17 \pm 0.03$ \\
\hline $\begin{array}{l}{ }^{4} \text { Extractable } \mathrm{P}(\mathrm{mg} \\
\left.\mathrm{P}_{2} \mathrm{O}_{5} \mathrm{~kg}^{-1}\right)\end{array}$ & $16 \pm 2.65$ & $26 . \pm 4.00$ \\
\hline $\begin{array}{l}{ }^{4} \text { Extractable } \mathrm{K} \text { (mg } \\
\left.\mathrm{K}_{2} \mathrm{O} \mathrm{kg}^{-1}\right)\end{array}$ & $78 \pm 8.74$ & $63 \pm 7.21$ \\
\hline $\begin{array}{l}{ }^{5} \text { Extractable B (mg } \\
\mathrm{kg}^{-1} \text { ) }\end{array}$ & $0.61 \pm 0.03$ & $0.47 \pm 0.04$ \\
\hline $\begin{array}{l}{ }^{6} \text { Exchang. Ca }\left(\mathrm{cmol}_{\mathrm{c}}\right. \\
\left.\mathrm{kg}^{-1}\right)\end{array}$ & $9.08 \pm 0.50$ & $10.93 \pm 0.22$ \\
\hline $\begin{array}{l}{ }^{6} \text { Exchang. } \mathrm{Mg}\left(\mathrm{cmol}_{\mathrm{c}}\right. \\
\left.\mathrm{kg}^{-1}\right)\end{array}$ & $4.45 \pm 0.13$ & $6.03 \pm 0.20$ \\
\hline $\begin{array}{l}{ }^{6} \text { Exchang. } \mathrm{K}\left(\mathrm{cmol}_{\mathrm{c}}\right. \\
\left.\mathrm{kg}^{-1}\right)\end{array}$ & $0.25 \pm 0.02$ & $0.20 \pm 0.01$ \\
\hline $\begin{array}{l}{ }^{6} \text { Exchang. } \mathrm{Na}\left(\mathrm{cmol}_{\mathrm{c}}\right. \\
\left.\mathrm{kg}^{-1}\right)\end{array}$ & $0.77 \pm 0.03$ & $0.21 \pm 0.02$ \\
\hline $\begin{array}{l}{ }^{8} \text { Exchang. acidity } \\
\left(\mathrm{cmol}_{\mathrm{c}} \mathrm{kg}^{-1}\right)\end{array}$ & $0.00 \pm 0.00$ & $0.23 \pm 0.01$ \\
\hline 6CTCe $\left(\mathrm{cmol} \mathrm{kg}^{-1}\right)^{4}$ & $14.55 \pm 0.64$ & $17.61 \pm 0.42$ \\
\hline
\end{tabular}

1: Potentiometry; ${ }^{2}$ Walkley-Black; ${ }^{3}$ Kjeldahl; ${ }^{4}$ Ammonium lactate (EgnerRiehm); ${ }^{5}$ Hot water, azomethine-H; ${ }^{6}$ Ammonium lactate; ${ }^{7}$ Potassium chloride.

(P00) and $200(\mathrm{P} 200) \mathrm{kg} \mathrm{P}_{2} \mathrm{O}_{5} \mathrm{ha}^{-1}$, corresponding to 0.0, $21.8,43.7$ and $87.3 \mathrm{~kg} \mathrm{P} \mathrm{ha}^{-1}$. The experiment was arranged as a split-block since the operations involved make it difficult to handle all the factor combinations in the same manner (Little \& Hills, 1978). Soil conditioners were assigned to whole plots and $\mathrm{P}$ rates to subplots in an experimental design with three replicates. The size of each experimental unit was $12 \mathrm{~m}^{2}(4 \mathrm{~m} \times 3 \mathrm{~m})$.

The zeolite use in this experiment is a clinoptilolite-based aluminosilicate (Fertecel®, Zeo Group) whose properties are presented in Table 2. Biochar was obtained in a pyrolytic reactor from wood biomass of silver wattle (Acacia dealbata).
The main properties of the commercial product (Ecochar ${ }^{\circledR}$, Ibero Massa Florestal, S.A.) are also presented in Table 2. P was applied as calcium superphosphate $\left(18 \% \mathrm{P}_{2} \mathrm{O}_{5}\right)$. Zeolite was used in a rate of $5 \mathrm{tha}^{-1}$ and biochar in a rate of $10 \mathrm{tha}^{-1}$ as recommended by vendors. All plots received also a basal fertilization plan of $150 \mathrm{~kg} \mathrm{ha}^{-1}$ of $\mathrm{K}_{2} \mathrm{O}$ (applied as potassium chloride, $60 \% \mathrm{~K}_{2} \mathrm{O}$ ) and $150 \mathrm{~kg} \mathrm{ha}^{-1}$ of $\mathrm{N}$ (as ammonium nitrate, $27 \% \mathrm{~N}$ ). Nitrogen was split into two applications, $50 \%$ at pre-plant and $50 \%$ as side-dressing.

The field experiment involved two summer growing seasons of forage maize and two winter growing seasons of oats. The experiment started in the spring of 2018. The soil was plowed to $25 \mathrm{~cm}$ deep, following by chiselling to level the ground. Subsequently, the amendments and fertilizers reported in the experimental design and those of the basal fertilization plan were manually distributed on the grown and incorporated with a last pass of cultivator. In 2018, soil preparation and fertilizers and amendments application were taken on May 15th and sowing on May 16th. A mid-season (FAO 500) maize hybrid (Monero) was used in this experiment and sowed at a density of 80,000 plants ha ${ }^{-1}$, spaced at 0.70 and $0.18 \mathrm{~m}$ between and in the rows, respectively. Maize received a herbicide treatment (active ingredients, isoxadifenethyl $\left[22 \mathrm{~g} \mathrm{~L}^{-1}\right]$ and tembotrione $\left[44 \mathrm{~g} \mathrm{~L}^{-1}\right]$ ) applied in a concentration of $0.5 \mathrm{~L} \mathrm{hl}^{-1}\left(2 \mathrm{~L} \mathrm{ha}^{-1}\right)$ at the phenological stage 14 (four unfolded leaf) (Meier, 2001), on 7th July 2018. Sidedress $\mathrm{N}$ was applied thereafter in the same day. During the summer, the maize was sprinkled irrigated with a central pivot. The machine irrigates simultaneously a field of 9 ha by applying $400 \mathrm{~mm} \mathrm{ha}^{-1} \mathrm{yr}^{-1}$. The harvest took place on 7 th September 2018, in the growth stage 73 (early milk).

In October 2018, oats crop (cultivar Boa Fé) was sown after a brief soil preparation with cultivator. The oats crop was not fertilized. Sowing took place on 23rd October 2018. The sowing rate was $130 \mathrm{~kg}$ seed $\mathrm{ha}^{-1}$. No other cropping practices were carried out on oats until harvest (at full flowering, growth stage 65) on 07th May 2019.

On 27th May 2019, maize was installed in a procedure very similar to the previous year, including the application of $\mathrm{P}$ of the experimental design and the basal fertilization plan. The exceptions were the soil conditioners biochar and 


\begin{tabular}{|c|c|c|c|}
\hline \multicolumn{2}{|l|}{ Zeolite } & \multicolumn{2}{|l|}{ Biochar } \\
\hline Particle size (mm) & $0.4-3.0$ & Particle size (mm) & $0.1-10$ \\
\hline Water holding capacity (\%) & 15.5 & Bulk density $\left(\mathrm{kg} \mathrm{m}^{-3}\right)$ & $350-400$ \\
\hline $\begin{array}{l}\text { Cation exch. capacity }\left(\mathrm{cmol}_{\mathrm{c}}\right. \\
\left.\mathrm{kg}^{-1}\right)\end{array}$ & 157 & Moisture (\%) & $\leq 30.0$ \\
\hline $\mathrm{pH}$ & 7.6 & Conductivity $\left(\mu \mathrm{S} \mathrm{cm}^{-1}\right)$ & 948 \\
\hline Bulk density $\left(\mathrm{kg} \mathrm{m}^{-3}\right)$ & 980 & $\mathrm{pH}$ & $<9$ \\
\hline $\mathrm{SiO}_{2}(\%)$ & 63.00 & Total organic C (\%) & $\geq 90.0$ \\
\hline $\mathrm{TiO}_{2}(\%)$ & 0.45 & Ash (\%) & $\leq 5.0$ \\
\hline $\mathrm{Al}_{2} \mathrm{O}_{3}(\%)$ & 11.57 & Volatile (\%) & $\leq 5.0$ \\
\hline $\mathrm{Fe}_{2} \mathrm{O}_{3}(\%)$ & 1.87 & Total $N\left(\mathrm{~g} \mathrm{~kg}^{-1}\right)$ & $\leq 5.0$ \\
\hline $\mathrm{FeO}(\%)$ & 0.81 & $\mathrm{Cd}\left(\mathrm{mg} \mathrm{kg}^{-1}\right)$ & $<0.05$ \\
\hline $\operatorname{MgO}(\%)$ & 0.92 & $\mathrm{~Pb}\left(\mathrm{mg} \mathrm{kg}^{-1}\right)$ & 0.05 \\
\hline $\mathrm{CaO}(\%)$ & 5.78 & $\mathrm{Fe}\left(\mathrm{mg} \mathrm{kg}^{-1}\right)$ & 99.5 \\
\hline $\mathrm{Na}_{2} \mathrm{O}(\%)$ & 2.39 & As $\left(\mathrm{mg} \mathrm{kg}^{-1}\right)$ & $<0.10$ \\
\hline $\mathrm{K}_{2} \mathrm{O}(\%)$ & 1.49 & $\mathrm{Hg}\left(\mathrm{mg} \mathrm{kg}^{-1}\right)$ & $<0.10$ \\
\hline $\mathrm{P}_{2} \mathrm{O}_{5}(\%)$ & 0.09 & & \\
\hline $\mathrm{H}_{2} \mathrm{O}(\%)$ & 3.44 & & \\
\hline
\end{tabular}

TABLE 2 Properties of the zeolite and biochar used in this study as provided by the manufacturers zeolites which were only applied in the first year. The herbicide was applied on 17th July 2019 (at four unfolded leaves). Maize harvest occurred on 19th September 2019 (at early milk stage). In the second year, oats crop was sown on 30th October 2019 and harvested on 12th May 2020. Also as in the first year, oats crop was not fertilized.

\subsection{Pot experiment}

In the pot experiment, only maize was grown in the summer period, during two consecutive years (2018 and 2019). Six treatments, consisting of biochar, zeolites and a non-amended treatment, fertilized with $\mathrm{P}$ (Biochar $+\mathrm{P}$, Zeolites $+\mathrm{P}$ and $\mathrm{P}$ ) and not fertilized with $\mathrm{P}$ (Biochar, Zeolites and Control) were arranged in a completely randomized design with four replicates. The pots were filled with $8 \mathrm{~kg}$ of dry and sieved (4 mm mesh) soil after had been mixed with the amendments and fertilizers. There were used $35.7 \mathrm{~g} \mathrm{pot}^{-1}$ of biochar and $17.8 \mathrm{~g} \mathrm{pot}^{-1}$ of zeolites. $\mathrm{P}$ was applied at a rate of $2.0 \mathrm{~g} \mathrm{P}_{2} \mathrm{O}_{5}$ pot $^{-1}$ (11.1 g superphosphate, $18 \% \mathrm{P}_{2} \mathrm{O}_{5}$ ). All pot received also a basal fertilization plan with $2.0 \mathrm{~g} N(7.4 \mathrm{~g}$ ammonium nitrate, $27 \% \mathrm{~N})$ and $2.0 \mathrm{~g} \mathrm{~K}_{2} \mathrm{O}$ (3.3 g potassium chloride, $60 \% \mathrm{~K}_{2} \mathrm{O}$ ). Biochar and zeolites were only applied in the first growing season and the fertilizers in both years. In 2018, maize was sown on May 23rd and in 2019 on May 29th. Three seeds of the hybrid Monero were sown in each pot. One week after emergence, the seedlings were thinned to a single one (the most vigorous) per plot. The pots were weeded as needed. The plants were also watered manually by applying $500 \mathrm{ml}$ water in each irrigation. The number of weekly waterings varied greatly throughout the year, depending on the environmental conditions and growth stages of maize. The irrigation frequency was adjusted in order to avoid exceeding the field capacity and to create anaerobic conditions. Plates were placed under the pots to prevent nutrient loss from leaching. The pots were kept outdoors during the experimental period. They were wrapped externally by white paper to reduce the effect of solar radiation on the heating of soil on the hottest summer days.

\subsection{Measurements in field and pot experiments and sample collection}

The portable SPAD (Soil and Plant Analysis Development)-502 Plus chlorophyll meter (Spectrum Technologies, Inc.) was used in maize (in the field and pot experiments) to estimate the leaf greenness. In the field, thirty readings for each measurement were taken from the middle of the blade of the youngest fully expanded leaves. In the pot experiment, five readings for each plant were taken from the youngest fully expanded leaf. In the field, the measurements were performed on 03rd August 2018 and 08th August 2019 and in pot experiment on 28th July 2018 and 11 th July 2019.

A normalized difference vegetation index (NDVI) was estimated in maize crop (field and pot experiments) by using the hand-held FieldScout CM 1,000 (Spectrum Technologies, Inc.). The meter senses and measures the ambient light at the wavelength of $660 \mathrm{~nm}$ and the reflected light (non-absorbed 
FIG URE 2 Maize dry matter (DM) yield as a function of soil conditioner (C) and $\mathrm{P}$ rate $[0$ (P0), 50 (P50), 100 (P100), 200 (P200) kg $\mathrm{P}_{2} \mathrm{O}_{5}$ ha $^{-1}$ ]. Within soil conditioners, $\mathrm{P}$ rates and years, means followed by the same letter are not significantly different by Tukey's HSD test $(\alpha=0.05)$. Vertical bars are the standard errors

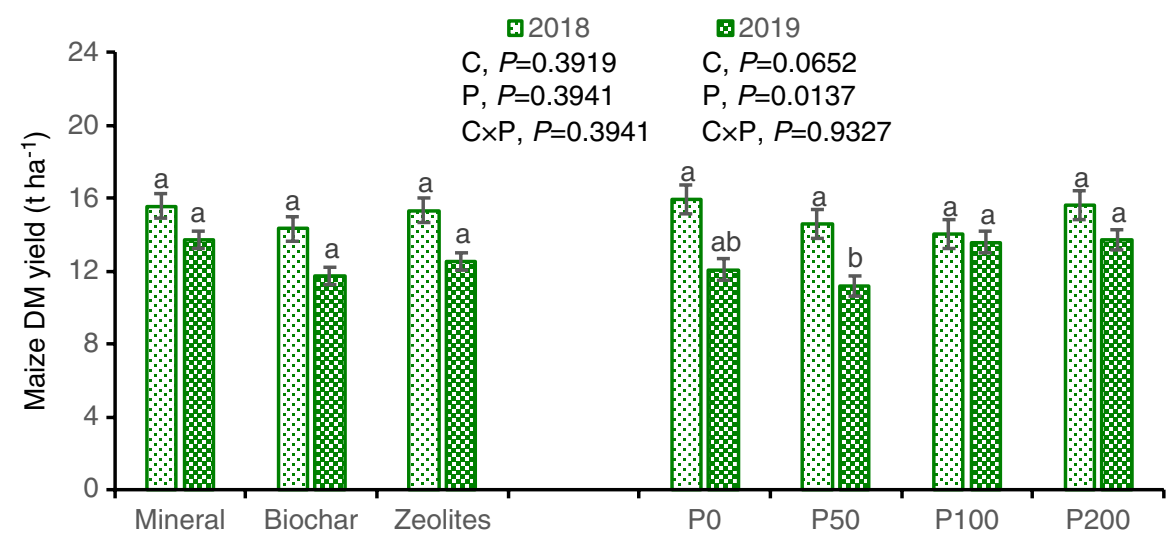

by leaf chlorophyll) at $840 \mathrm{~nm}$ wavelength. The measurements were taken in the same leaf part and dates as SPAD readings.

The OS-30p + chlorophyll meter (Opti-sciences, Inc.) was used to estimate chlorophyll $a$ fluorescence and OJIP transient through the dark adaptation protocols $\mathrm{F}_{\mathrm{V}} / \mathrm{F}_{\mathrm{M}}, \mathrm{F}_{\mathrm{V}} / \mathrm{F}_{0}$ and the advanced JIP test. $\mathrm{F}_{\mathrm{M}}, \mathrm{F}_{0}$ and $\mathrm{F}_{\mathrm{V}}$ are, respectively, maximum, minimum and variable fluorescence from dark-adapted leaves. The variables $\mathrm{F}_{\mathrm{V}} / \mathrm{F}_{\mathrm{M}}$ and $\mathrm{F}_{\mathrm{V}} / \mathrm{F}_{0}$ were estimated as $\mathrm{F}_{\mathrm{V}} /$ $\mathrm{F}_{\mathrm{M}}=\left(\mathrm{F}_{\mathrm{M}}-\mathrm{F}_{0}\right) / \mathrm{F}_{\mathrm{M}}$ and $\mathrm{F}_{\mathrm{V}} / \mathrm{F}_{0}=\left(\mathrm{F}_{\mathrm{M}^{-}}-\mathrm{F}_{0}\right) / \mathrm{F}_{0}$. The JIP test gives origin fluorescence at $20 \mu \mathrm{s}(\mathrm{O})$, fluorescence at $2 \mathrm{~ms}(\mathrm{~J})$, fluorescence at $30 \mathrm{~ms}(\mathrm{I})$ and maximum fluorescence $\left(\mathrm{P}\right.$, or $\left.\mathrm{F}_{\mathrm{M}}\right)$. Measurements were taken in the maize experiments from the middle of the blade of the youngest fully expanded leaves, after a period of dark adaptation longer than $35 \mathrm{~min}$, in the dates mentioned above.

In the field experiment, samples of the youngest fully matured leaves were also taken on the same date of the use of portable devices. These samples were carried out to the laboratory, oven-dried at $70^{\circ} \mathrm{C}$ and analysed for elemental composition to assess crop nutritional status.

In the field experiment, maize samples of $0.7 \mathrm{~m}^{2}(1 \mathrm{~m} \mathrm{lin}-$ ear in a central line of the plot) were cut on 07th September 2018 and 19th September 2019. The samples were weighed in fresh in the field. Still in the field, representative sub-samples were weighed again in fresh and carried out to the laboratory. After drying at $70{ }^{\circ} \mathrm{C}$, the sub-samples were weighed dry, to allow estimating DM yield per unit area, and thereafter ground for elemental analysis. The samples of the pot experiment were cut, oven-dried at $70{ }^{\circ} \mathrm{C}$, weighed and ground for elemental analysis.

Oats crop samples of $0.5 \mathrm{~m}^{2}$ were cut in the central part of the experimental units on May 7th and 12th, in 2018 and 2019 , respectively. The samples were oven-dried at $70^{\circ} \mathrm{C}$ and ground for elemental analysis.

In the field, the soils were sampled after maize harvest on 16th October 2018 and 30th October 2019 and after oats harvest on 20th May 2020. Composite samples were collected from each experimental unit, consisting on sampling in six random points to create each composite sample. Soil samples were also taken from pot experiment in the day after the cut of maize. The pot soil was turned over and a $500 \mathrm{~g}$ sample recovered and sent to the laboratory.

\section{$2.4 \quad$ Laboratory analyses}

The soil samples were oven-dried at $40{ }^{\circ} \mathrm{C}$ and sieved in a mesh of $2 \mathrm{~mm}$. The samples were analysed for (a) $\mathrm{pH}\left(\mathrm{H}_{2} \mathrm{O}\right.$, $\mathrm{KCl}$ ) (soil: solution, 1:2.5); (b) cation-exchange capacity (ammonium acetate, $\mathrm{pH}$ 7.0) and exchange acidity ( $\mathrm{KCl}$ extraction); (c) easily oxidizable $\mathrm{C}$ (wet digestion, Walkley-Black method); (d) total organic $\mathrm{C}$ (incineration); (e) extractable $\mathrm{P}$ and $\mathrm{K}$ (ammonium lactate); (f) extractable B (hot water extraction and azomethine-H methods); (g) extractable Fe, Mn, $\mathrm{Zn}$ and $\mathrm{Cu}$ (ammonium acetate and EDTA, determined by atomic absorption spectrometry); (h) labile $\mathrm{P}$ fraction, $\mathrm{P}$-res (extraction of inorganic $\mathrm{P}$ with the $\mathrm{HCO}_{3}{ }^{-}$ion present in an anion exchange resin, and then eluted in acid media) and $\mathrm{P}$ bic (inorganic $\mathrm{P}$ extracted by $\mathrm{NaHCO}_{3} 0.5 \mathrm{M}$ ) and; (i) acid phosphatase activity (determined from the conversion of nitrophenylphosphate to nitrophenolphosphate). In the initial samples, there were also determined (j) soil separates (clay, silt and sand fractions) (Robinson pipette method). Methods $1-4$ and 7-8, and 10 are fully described by Van Reeuwijk (2002), method 5 by Balbino (1968), method 6 by Jones (2001) and method 9 by Alef et al. (1995).

Elemental tissue analyses were performed by Kjeldahl $(\mathrm{N})$, colorimetry (B and $\mathrm{P}$ ), flame emission spectrometry (K) and atomic absorption spectrophotometry $(\mathrm{Ca}, \mathrm{Mg}, \mathrm{Cu}$, $\mathrm{Fe}, \mathrm{Zn}$ and $\mathrm{Mn}$ ) methods after nitric digestion of the samples (Temminghoff \& Houba, 2004).

\section{5 | Data analysis}

The field experiment was arranged as a split-block design. In the split-block design soil conditioning (whole plots), $\mathrm{N}$ rates (subplots) and interaction (soil conditioning $\times \mathrm{N}$ rates) were treated as fixed and blocks as random factors in 


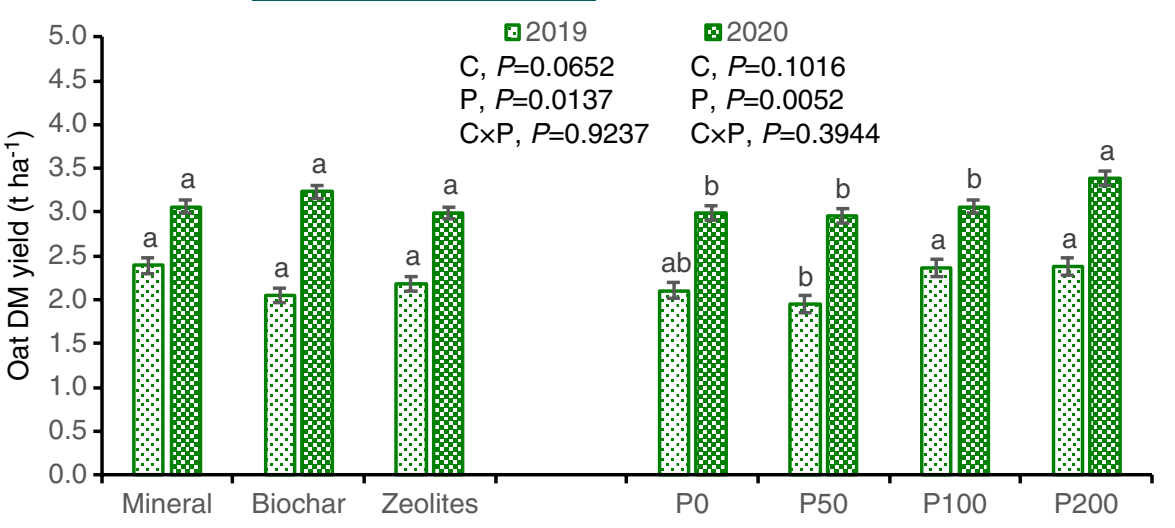

F I G URE 3 Oat dry matter (DM) yield as a function of soil conditioner (C) and $\mathrm{P}$ rate $[0$ (P0), 50 (P50), 100 (P100), 200 (P200) $\left.\mathrm{kg} \mathrm{P}_{2} \mathrm{O}_{5} \mathrm{ha}^{-1}\right]$. Within soil conditioners, $\mathrm{P}$ rates and years, means followed by the same letter are not significantly different by Tukey's HSD test $(\alpha=0.05)$. Vertical bars are the standard errors the ANOVA model. One-way ANOVA was performed to data of the pot experiment. Data of both experimental designs were treated separated by year. In both experiments, after ANOVA examination, the means with significant differences $(\alpha<0.05)$ were separated by Tukey HSD test $(\alpha=0.05)$.

\section{3 | RESULTS}

\section{1 | Field experiment}

Maize DM yield did not significantly vary between soil conditioners in 2018 or 2019 (Figure 2). The use of higher P rates (P200) did not increase DM yield in 2018. In 2019, significant differences between $\mathrm{P}$ rates were found, and DM yields tended to increase as the $\mathrm{P}$ rate increased. However, the lower and higher average values were, respectively, found in P50 (11.2 $\mathrm{t} \mathrm{ha}^{-1}$ ) and P200 (13.7 $\mathrm{t} \mathrm{ha}^{-1}$ ) treatments. Strictly speaking, DM yields did not significantly varies between P0 and P200 treatment.

In the field experiment, maize leaf $\mathrm{P}$ concentration, in $34 / 35$ growth stage (4 to 5 nodes detectable), did not vary significantly with soil conditioners or with the rate of $\mathrm{P}$ in any of the years (data not shown). The average values varied between 23.4 and $25.2 \mathrm{~g} \mathrm{~kg}^{-1}$ in 2018 and between 25.8 and $28.6 \mathrm{~g} \mathrm{~kg}^{-1}$ in 2019. Likewise, the levels of $\mathrm{N}$ and $\mathrm{K}$ in the leaves also did not vary significantly with the soil conditioners or with the rates of P. Leaf Ca concentrations were significantly lower in the biochar treatment in 2018, but the result was not repeated in 2019, in which significant differences between soil conditioners were not found. Significant differences in leaf $\mathrm{Ca}$ levels between $\mathrm{P}$ rates were also not found. In the case of $\mathrm{Mg}$, the levels in the leaves were significantly higher and significantly lower, respectively, in the zeolites and biochar treatments in comparison to the control. The result, however, was also not maintained in 2019, in which significant differences between the treatments were not found. Regarding the concentration of micronutrients $\mathrm{B}, \mathrm{Fe}, \mathrm{Mn}, \mathrm{Cu}$ and $\mathrm{Zn}$ in the leaves, significant effects were not found nor any coherent trend in the results due to the application of soil conditioners or between $\mathrm{P}$ rates.

Other potential indicators of the nutritional status of maize plants, such as SPAD-readings and NDVI, and the photosynthetic performance of plants, such as chlorophyll $a$ fluorescence transient, determined in the field experiment of maize also showed little sensitivity to the application of soil conditioners or $\mathrm{P}$ rates (data not shown). The elemental composition of whole aboveground plant tissues at harvest also did not provide relevant information on the effect of treatments on the maize crop. Significant differences in tissue $\mathrm{P}$ concentration or in the concentration of the other nutrients analysed were not found (data not shown).

Soil conditioners did not significantly influence the DM yield of oats in any of the years (Figure 3). P fertilization, in turn, tended to increase oat DM yield. Significant differences were found in both years and the higher rates of applied $\mathrm{P}$ gave the higher average DM yields.

The concentration of $\mathrm{P}$ in oat tissues did not significantly change with soil conditioners or $\mathrm{P}$ rates. However, the average values showed a consistent slight increase with $\mathrm{P}$ rates in both years, with the higher values to be found in P200 treatment. In May 2019 and 2020, average P tissue concentrations increased, respectively, from 2.01 to 2.12 and 1.92 to 2.13 from P0 to P200 treatments. The concentration of other nutrients in oat tissue did not show any consistent trend due to the use of soil conditioners or $\mathrm{P}$ rates (data not shown).

\section{2 | Pot experiment}

Maize DM yield in the pot experiment appeared clearly separated into two groups of treatments, those that received and those that did not receive $\mathrm{P}$ (Figure 4). Biochar and zeolites did not show significant differences to the non-amended treatment. In 2019, maize DM yield dropped to less than half the values recorded in 2018 .

The concentration of $\mathrm{P}$ in plant tissue significantly vary between treatments. In 2018, two groups were formed, the first group by the treatments that did not receive $\mathrm{P}$ as a fertilizer 
F I G URE 4 Maize dry matter (DM) yield in the pot experiment. Within years, means followed by the same letter are not significantly different by Tukey's HSD test $(\alpha=0.05)$. Vertical bars are the standard errors
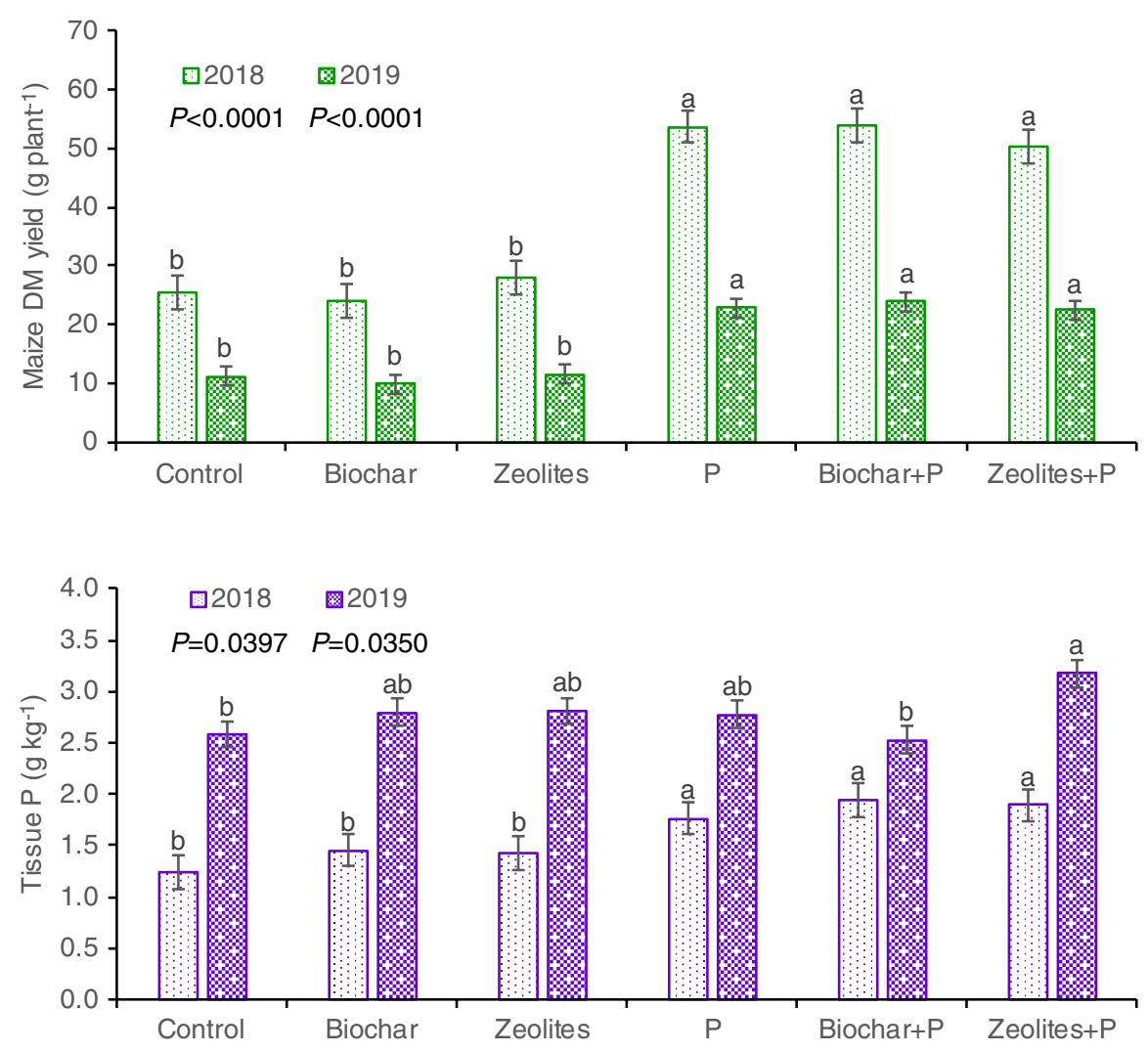

FIGURE 5 Maize tissue phosphorus (P) concentration in the pot experiment. Within years, means followed by the same letter are not significantly different by Tukey's HSD test ( $\alpha=0.05)$. Vertical bars are the standard errors which registered significantly lower tissue $\mathrm{P}$ concentrations (Figure 5). The second group was formed by the treatments that received $\mathrm{P}$ as a fertilizer which displayed significantly higher tissue P levels. In 2019, the results of P tissue levels are less easy to interpret. Zeolites treatments gave the average higher values which were significantly different than those of the control and biochar + P treatments. In 2019, the average values of the different treatments were clearly higher than the values of 2018. In 2018, average values varied from 1.24 to $1.94 \mathrm{~g} \mathrm{~kg}^{-1}$ and in 2019 from 2.53 to $3.18 \mathrm{~g} \mathrm{~kg}^{-1}$.

The concentration of other macronutrients in the plant tissues varied in a way that can still be related to the treatments (Table 3). Zeolites significantly increased tissue $\mathrm{K}$ levels in 2018 in comparison with the control and in 2019 the average value persisted the highest, although not significantly different than those of the other treatments. In 2018, the treatments that received $\mathrm{P}$ and recorded higher plant $\mathrm{DM}$ yields showed tendency to display lower $N$ values than the treatments that did not receive P. There seems to be a similar trend for K, although in the control treatment tissue $\mathrm{K}$ values were low, at the levels of the treatments that received P. Regarding $\mathrm{Ca}$ and $\mathrm{Mg}$, the treatments that received $\mathrm{P}$ and gave higher $\mathrm{DM}$ yields showed lower $\mathrm{Ca}$ and $\mathrm{Mg}$ concentrations in the tissues in comparison to the treatments that did not receive P. All this seemed to be the result of a dilution effect. In 2019, completely disappeared the effect of the treatments, in line with DM yield which also varied less in 2019 .
The concentration of the micronutrients analysed $(\mathrm{B}, \mathrm{Fe}$, $\mathrm{Mn}, \mathrm{Cu}$ and $\mathrm{Zn}$ ) in the tissues did not vary significantly with fertilizer treatments, and no relevant trends were observed, even considering the two years of harvest (data not shown). However, some differences between years should be mentioned. The levels of B doubled in 2019 (4.8 to $9.0 \mathrm{mg} \mathrm{kg}^{-1}$ in 2018 and 2019), and the levels of $\mathrm{Zn}$ also recorded a great increase (18.1 and $26.0 \mathrm{mg} \mathrm{kg}^{-1}$ in 2018 and 2019). The levels of Fe reduced slightly from 2018 to 2019 and the concentrations of the other nutrients persisted at similar levels.

The treatments had a little influence on the variables determined in the field by the tools used to monitor the nutritional status and the general photosynthetic performance of the plants (Table 4). SPAD-readings did not vary between fertilizer treatments in any of the years. NDVI showed a significant increase in 2019 in the treatments that received P. Chlorophyll $a$ fluorescence transient variables (JIP test, $\mathrm{F}_{\mathrm{V}} /$ $\left.\mathrm{F}_{0}, \mathrm{~F}_{\mathrm{V}} / \mathrm{F}_{\mathrm{M}}\right)$ also showed little sensitivity to the effect of the different treatments. However, the values of $\mathrm{F}_{\mathrm{V}} / \mathrm{F}_{\mathrm{M}}$ were lower in 2019 (the less productive year) in comparison with those of 2018 .

\section{3 | Soil properties}

From the field trial, soil analyses of the samples collected in October 2018, October 2019 and May 2020 revealed no 
TA B L E 3 Macronutrient concentration in maize aboveground dry mass. In columns, means followed by the same letter are not statistically different by Tukey HSD test $(\alpha=0.05)$

\begin{tabular}{|c|c|c|c|c|c|c|c|c|}
\hline \multirow[b]{3}{*}{ Control } & \multicolumn{4}{|l|}{2018} & \multicolumn{4}{|l|}{2019} \\
\hline & $\mathbf{N}$ & $\mathbf{K}$ & $\mathrm{Ca}$ & Mg & $\mathbf{N}$ & $\mathbf{K}$ & $\mathbf{C a}$ & Mg \\
\hline & $9.1 \mathrm{a}$ & $20.8 \mathrm{~b}$ & $3.2 \mathrm{a}$ & $1.8 \mathrm{ab}$ & $6.3 \mathrm{a}$ & $20.5 \mathrm{a}$ & $1.8 \mathrm{a}$ & $1.6 \mathrm{a}$ \\
\hline Biochar & $8.4 a b$ & $23.2 \mathrm{ab}$ & $3.1 \mathrm{a}$ & $1.9 \mathrm{a}$ & $6.7 \mathrm{a}$ & $21.6 \mathrm{a}$ & $1.8 \mathrm{a}$ & $1.7 \mathrm{a}$ \\
\hline $\mathrm{P}$ & $6.4 \mathrm{~b}$ & $20.6 \mathrm{~b}$ & $1.8 \mathrm{~b}$ & $1.5 \mathrm{~b}$ & $7.0 \mathrm{a}$ & $22.8 \mathrm{a}$ & $1.9 \mathrm{a}$ & $1.8 \mathrm{a}$ \\
\hline Biochar $+\mathrm{P}$ & $6.6 \mathrm{ab}$ & $18.5 \mathrm{~b}$ & $2.2 \mathrm{~b}$ & $1.5 \mathrm{~b}$ & $7.3 \mathrm{a}$ & $21.0 \mathrm{a}$ & $1.8 \mathrm{a}$ & $1.5 \mathrm{a}$ \\
\hline Zeolites + P & $7.1 \mathrm{ab}$ & $20.6 \mathrm{~b}$ & $1.8 \mathrm{~b}$ & $1.5 \mathrm{~b}$ & $5.9 \mathrm{a}$ & $22.8 \mathrm{a}$ & $2.0 \mathrm{a}$ & $1.6 \mathrm{a}$ \\
\hline Prob $>$ F & 0.0147 & 0.0034 & $<0.0001$ & 0.0002 & 0.6483 & 0.1517 & 0.0927 & 0.1397 \\
\hline
\end{tabular}

\begin{tabular}{|c|c|c|c|c|c|c|}
\hline & \multicolumn{3}{|l|}{2018} & \multicolumn{3}{|l|}{2019} \\
\hline & NDVI & SPAD & $\mathbf{F}_{\mathbf{V} /} \mathbf{F}_{\mathbf{M}}$ & NDVI & SPAD & $\mathbf{F}_{\mathbf{V} /} \mathbf{F}_{\mathbf{M}}$ \\
\hline Control & $0.66 \mathrm{a}$ & $26.1 \mathrm{a}$ & $0.76 \mathrm{a}$ & $0.66 \mathrm{~b}$ & $30.9 \mathrm{a}$ & $0.69 \mathrm{a}$ \\
\hline Biochar & $0.63 \mathrm{a}$ & $26.7 \mathrm{a}$ & $0.75 \mathrm{a}$ & $0.64 \mathrm{~b}$ & $28.5 \mathrm{a}$ & $0.71 \mathrm{a}$ \\
\hline Zeolites & $0.64 \mathrm{a}$ & $28.3 \mathrm{a}$ & $0.76 \mathrm{a}$ & $0.64 \mathrm{~b}$ & $28.6 \mathrm{a}$ & $0.71 \mathrm{a}$ \\
\hline $\mathrm{P}$ & $0.66 \mathrm{a}$ & $27.9 \mathrm{a}$ & $0.77 \mathrm{a}$ & $0.69 \mathrm{a}$ & $37.6 \mathrm{a}$ & $0.71 \mathrm{a}$ \\
\hline Biochar $+\mathrm{P}$ & $0.68 \mathrm{a}$ & $28.9 \mathrm{a}$ & $0.76 \mathrm{a}$ & $0.68 \mathrm{ab}$ & $32.6 \mathrm{a}$ & $0.70 \mathrm{a}$ \\
\hline Zeolites + P & $0.65 \mathrm{a}$ & $28.5 \mathrm{a}$ & $0.77 \mathrm{a}$ & $0.71 \mathrm{a}$ & $31.8 \mathrm{a}$ & $0.72 \mathrm{a}$ \\
\hline Prob $>$ F & 0.1965 & 0.8383 & 0.5471 & 0.0059 & 0.1015 & 0.7603 \\
\hline
\end{tabular}

TABLE 4 Normalized difference vegetation index (NDVI), SPAD-readings and ratio of variable fluorescence to maximum fluorescence $\left(\mathrm{F}_{\mathrm{V} /} \mathrm{F}_{\mathrm{M}}\right)$. In columns, means followed by the same letter are not statistically different by Tukey HSD test $(\alpha=0.05)$
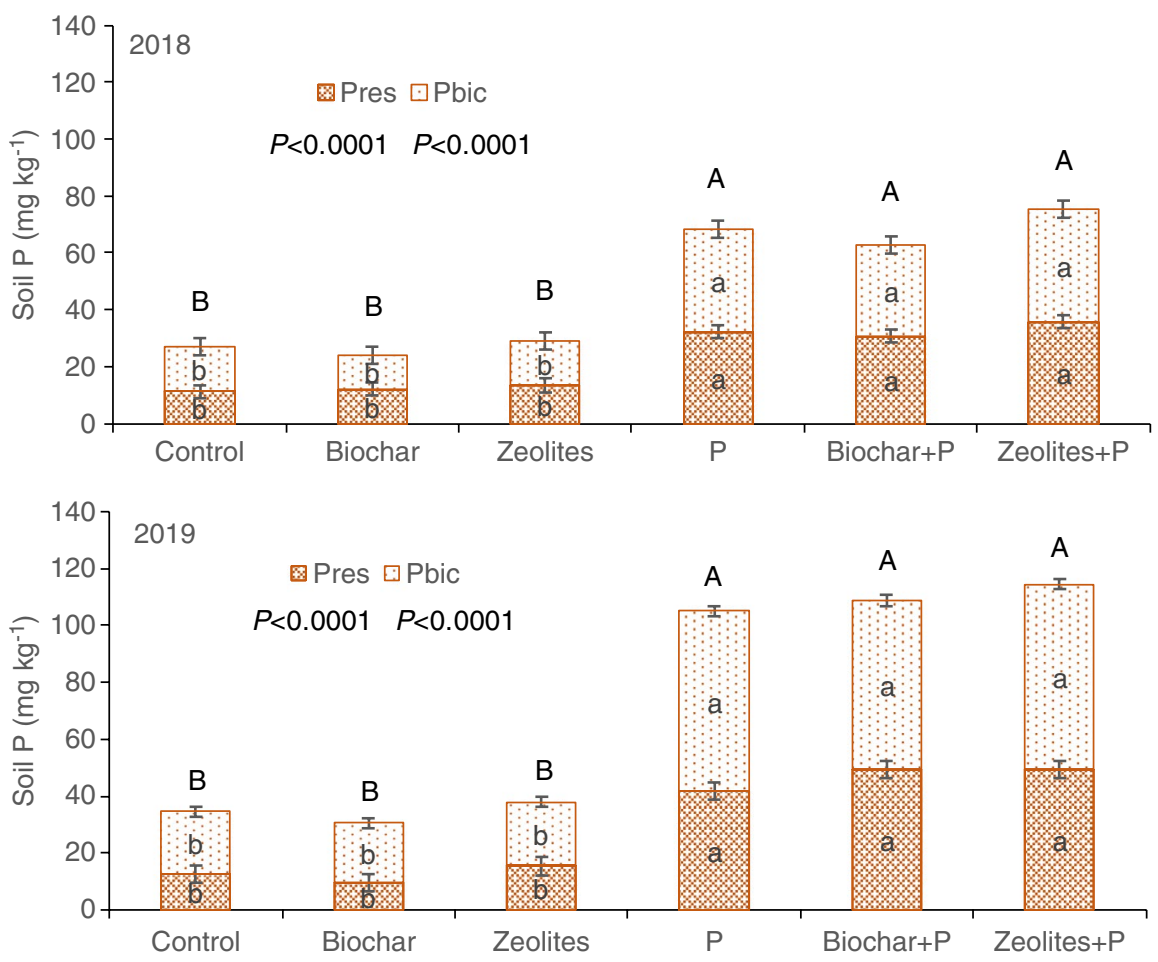

F I G URE 6 Soil phosphorus (P) extracted by anion exchange resins (Pres) and bicarbonate (Pbic) and total easily extracted P (Pres + Pbic). Means followed by the same letter within each extracted procedure (lowercase) and total (uppercase), are not significantly different by Tukey's HSD test $(\alpha=0.05)$. Vertical bars are the standard errors 
FIGURE 7 Acid phosphatase activity (APA) in the soil of the pot experiment. Means followed by the same letter within each year, are not significantly different by Tukey's HSD test $(\alpha=0.05)$. Vertical bars are the standard errors

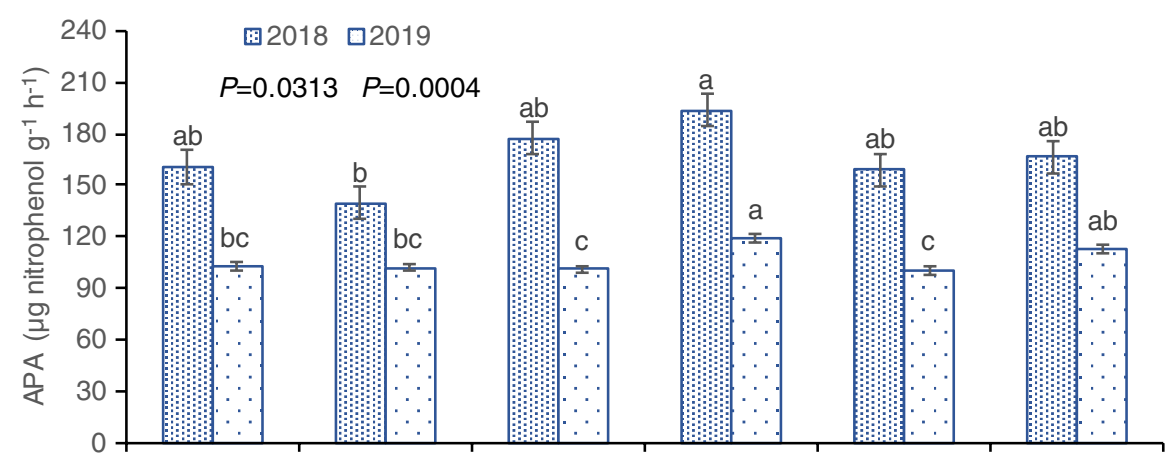

relevant differences due to the effect of soil conditioners (data not shown). However, it should be mentioned that the use of biochar significantly increased total organic $\mathrm{C}$ (incineration) but did not significantly increase easily oxidizable $\mathrm{C}$ (wet digestion, Walkley-Black). Soil extractable P (ammonium lactate-acetic acid) also increased in the treatments that received the higher rates of the nutrient, but a significant effect of the application of biochar and zeolites on soil extractable $\mathrm{P}$ was not found.

In general, biochar and zeolites did not significantly influence the main soil properties in the pot experiment, such as $\mathrm{pH}$, extractable $\mathrm{P}$ and $\mathrm{K}$ or the bases of the exchangeable complex (data not shown). As in the field experiment, biochar increased total organic $\mathrm{C}$ (incineration) but did not increase easily oxidizable $\mathrm{C}$. The application of $\mathrm{P}$ significantly increased extractable $\mathrm{P}$ and $\mathrm{Ca}$ content in the exchangeable complex and reduced soil $\mathrm{pH}$.

In the pot experiment, a partial soil $\mathrm{P}$ fractionation was performed by the determination of Pres and Pbic, which together provide the so-called easily available $\mathrm{P}$, or labile $\mathrm{P}$ (Figure 6). The results appeared in two different treatment groups, those that received $\mathrm{P}$ and those that did not receive $\mathrm{P}$. The labile $\mathrm{P}$ values were significantly higher in treatments that received mineral $P$. Biochar and zeolites, applied alone or combined with $\mathrm{P}$, did not reveal any significant effect on the levels of $\mathrm{P}$ in the soil. The values for 2019, in which there was produced less maize DM yield, appeared higher than in 2018.

The acid phosphatase activity tended to appear lower in the treatments that received biochar and zeolites if an overall observation is made of the two years of results (Figure 7). In 2018, the lowest average value was recorded in the biochar treatment and in 2019 in the Zeolites and Biochar + P treatments. However, the analysis made a small contribution to the general understanding of the results.

\section{4 | DISCUSSION}

Biochar did not increase the productivity of maize or oats in the field trials in comparison with the untreated control. A similar result was obtained from the pot experiment with maize. Biochar had a much-reduced effect on tissue nutrient concentrations, both in maize and oats grown in the field and in maize grown in pots. Biochar did not have a significant measurable effect on the main properties of the soil, either in the field trial or in the pot experiment. Biochar only significantly increased total organic C (incineration), as a result of its application and recalcitrance. Biochars typically have a molar $\mathrm{H} / \mathrm{C}$ ratio below that of the feedstock, particularly those obtained from wood biomass, which indicates polymerization, and hence potential recalcitrance of biochar products (Shaaban et al., 2018). From previous studies, the effect of biochar on soil properties and crop yield has been found to be from positive, to inconsistent or negative, and the same is true for soil $\mathrm{P}$ availability and $\mathrm{P}$ uptake by plants (Gao et al. 2019). Availability of $P$ to plants is increased by anion exchange capacity of biochar or by cations that interact with P (Gul \& Whalen, 2016; Shaaban et al., 2018). At low $\mathrm{pH}, \mathrm{P}$ fixation is mainly due to the reaction with $\mathrm{Fe}$ and $\mathrm{Al}$ oxides and precipitation as $\mathrm{AlPO}_{4}$ and $\mathrm{FePO}_{4}$. Above $\mathrm{pH}$ 7.0, Ca precipitates with $\mathrm{P}$ as $\mathrm{Ca}-\mathrm{P}$ minerals, decreasing P solubility (Havlin et al. 2014). Biochar may reduce the formation of precipitates and therefore increase the availability of P to plants (Cui et al., 2011; Shaaban et al., 2018; Zhang et al., 2016). Biochar amendments have also proven to influence soil enzyme composition. Also, while some studies have shown that the use of biochar increases the activity of acid phosphatase and alkaline phosphatase (Du et al., 2014; Masto et al., 2013), others have found that the activity of acid phosphatase is reduced by its application (Luo \& Gu, 2016). Most of the studies reporting increased $\mathrm{P}$ availability to plants following biochar applications were undertaken in degraded soils, such as acid or saline-sodic soils (Liu et al., 2017; Xu et al., 2016), or studies with low available soil P (Shaaban et al., 2018; Zhang et al., 2016). However, in this particular soil and cropping system, no clear benefits were obtained following the use of biochar. However, it should also be noted that biochar properties may depend on the feedstock material and temperature of pyrolysis (Gul \& Whalen, 2016; Zhang et al., 2016), variables that make it even more difficult to generalize the result of a particular experiment. 
Zeolites did not increase the productivity of maize or oats in the field trials in comparison with the untreated control and a similar result was obtained from the pot experiment with maize. Zeolites are characterized by high water holding capacity, high cation exchange capacity and high adsorption and catalytic properties (Bernardi et al., 2010; Ryakhovskaya \& Gainatulina, 2009). It has been reported that zeolites can improve crop productivity in saline soils (Noori et al., 2007) or improve $\mathrm{P}$ use efficiency by increasing $\mathrm{P}$ availability from phosphate rocks (Bernardi et al., 2010; Guaya et al., 2020). The ability of retaining both cations and anions has allowed the use of zeolites previously enriched in nutrients. These nutrient-enriched zeolites may act as a slow-release nutrient source for plants, reducing nutrient loss and increasing nutrient uptake (Liator et al., 2017). In this study, the direct application of zeolites to the soil did not reveal any relevant effect on soil properties, nor on traits found in plants. There was only observed an increase in K concentration in maize plants, probably due to the initial nutrient content on the material applied.

The application of $\mathrm{P}$ increased the DM produced in the second growing season of maize and in the two cycles of oats. In the pots, the application of $\mathrm{P}$ increased DM yield in the two years of testing. $\mathrm{P}$ is a limiting factor over large areas of the world. The response of plants to $\mathrm{P}$ application is reported in a wide range of crops (Ferreira et al., 2018; Türk et al., 2007; Wang et al., 2010; Watt \& Evans, 2003). However, most of these studies took place in soils that are inherently low in $\mathrm{P}$, often sandy or very acidic, where the limitations of $\mathrm{P}$ in the soil predispose them to the results. In this study, the levels of $\mathrm{P}$ in the soil were also low, which may justify the response of the crop to applied $\mathrm{P}$ that was found.

In the field trial, applied $\mathrm{P}$ did not significantly influence $\mathrm{P}$ levels in maize or oat tissues, in spite of the concentration of $\mathrm{P}$ in oat tissues have shown a consistent tendency to increase from P0 to P200 treatments. It seems that the soil's ability to provide $\mathrm{P}$ to the plants, and the increased biomass yield, reduced the effect of applied $\mathrm{P}$ on tissue nutrient concentration. In general terms, tissue $\mathrm{P}$ tends to fluctuate less than tissue concentration of many other nutrients, partly due to the buffering effect of the root system on the distribution of P in the shoots (Ferreira et al., 2018; Rodrigues et al., 2021). Furthermore, the increased biomass in response to applied $\mathrm{P}$ may have caused a dilution effect, a phenomenon well documented in the literature (Arrobas et al., 2018; Jarrel \& Beverly, 1981). In the field trial, the effect of applied P on the concentration of other nutrients in the tissues was also low.

The application of $\mathrm{P}$ increased $\mathrm{P}$ levels in the soil, mainly the labile $\mathrm{P}$ fraction (Pres and Pbic). The maintenance of the concentration of $\mathrm{P}$ in soil solution (intensity factor) depends on the capacity of adsorbed $\mathrm{P}$, mineral $\mathrm{P}$ and organic $\mathrm{P}$ (quantity factor) to replace $\mathrm{P}$ in the solution as a response of $\mathrm{P}$ taken up by plants (Havlin et al., 2014). The ratio between the intensity and quantity factors defines the buffer power of the soil or the relative capacity of the soil to buffer changes of $\mathrm{P}$ in solution. For a given soil, $\mathrm{P}$ adsorption is higher in soils with low initial amounts of adsorbed $\mathrm{P}$, as would be the initial situation in this soil. However, as the P-fertilizer is added and the amount of $\mathrm{P}$ adsorbed increases, the potential for further adsorption decreases. When all the adsorption sites are saturated with inorganic P, adsorption no longer occurs (Havlin et al., 2014). Thus, the increase in the $\mathrm{P}$ labile fraction recorded in this study was probably the effect of the progressive saturation of the $\mathrm{P}$ adsorption capacity due to the application of $\mathrm{P}$.

The application of $\mathrm{P}$ fertilizer also increased $\mathrm{pH}$ and calcium content in the exchangeable complex, by a direct effect of the nature and composition of the $\mathrm{P}$ fertilizer $\left(18 \% \mathrm{P}_{2} \mathrm{O}_{5}\right.$ and $16 \% \mathrm{Ca}$ ). On the other hand, the application of $\mathrm{P}$ did not have a visible effect on acid phosphatase activity. Although the activity of acid phosphatase tends to decrease with the availability of mineral P in the soil (Zheng et al., 2015), less obvious results are known to occur due to several environmental variables such as the influence of $\mathrm{pH}$ or organic matter (Ferreira et al., 2018; Rodrigues et al., 2020).

\section{5 | CONCLUSIONS}

Biochar and zeolites did not increase DM yield of maize and oats grown in the field, or DM yield of maize grown in the pots, whereas in general, the plants responded to the applied P. The effect of the soil conditioners on plant elemental composition was virtually nil, while the application of $\mathrm{P}$ significantly influenced the levels of $\mathrm{P}$ and other nutrients in the pot experiment. Soil conditioners did not have a measurable effect on most of the determined soil properties. In the biochar plots, the total organic $\mathrm{C}$ increased, due to the recalcitrance in the soil of the applied biochar $\mathrm{C}$, but not the easily oxidizable C. In the plots with zeolites, only the $\mathrm{K}$ content in the soil increased, certainly due to the presence of the element in the initial composition of the mineral. In spite of the short duration of the experiment (two years and four crops), in view of these results, biochars and zeolites with similar characteristics cannot be recommended for this type of soil and farming system due to the lack of measurable benefits for the farmer.

\section{CONFLICTS OF INTEREST}

The authors declare that they have no conflict of interest.

\section{ORCID}

Manuel Ângelo Rodrigues (iD https://orcid.

org/0000-0002-5367-1129

\section{REFERENCES}

Alef, K., Nannipieri, P. \& Trazar-Cepeda, C. (1995). Phosphatase activity. In K. Alef \& P. Nannipieri (Eds.), Methods in applied soil microbiology and biochemistry (pp. 214-215). Academic Press, . 
Arif, M., Ilyas, M., Riaz, M., Ali, K., Shah, K., Haq, I. U. \& Fahad, S. (2017). Biochar improves phosphorus use efficiency of organicinorganic fertilizers, maize-wheat productivity and soil quality in a low fertility alkaline soil. Field Crops Research, 214, 25-37. https:// doi.org/10.1016/j.fcr.2017.08.018

Arrobas, M., Ferreira, I. Q., Afonso, S. \& Rodrigues, M. A. (2018). Sufficiency ranges and crop nutrient removals for peppermint (Mentha $\mathrm{x}$ piperita L.) established from field and pot fertilizer experiments. Communications in Soil Science and Plant Analysis, 49(14), 1719-1730. https://doi.org/10.1080/00103624.2018.1474909

Assimakopoulou, A., Dimitroulia, D., Kosmidis, S. \& Doula, M. K. (2020). Growth, yield and nutrient status of pepper plants grown on a soil substrate with olive mill waste sludge and natural zeolite addition. Journal of Plant Nutrition, 43, 629-640. https://doi. org/10.1080/01904167.2019.1701030

Balbino, L. R. (1968). La méthode Egner-Riehm et la détermination du phosfore et du potassium «assimilável» des sols du Portugal. II Col. Medit Cont. Fert. Plantas Cultivadas, pp 55-65.

Bernardi, A. C. D. C., Bezerra, M., Monte, D. M., Renato, P., Paiva, P. \& Werneck, C. G. (2010). Dry matter production and nutrient accumulation after successive crops of lettuce, tomato, rice, and andropogon grass in a substrate with zeolite. Revista Brasileira Da Ciência do Solo, 34, 435-442. https://doi.org/10.1590/S0100-06832 010000200017

Cui, H. J., Wang, M. K., Fu, M. L. \& Ci, E. (2011). Enhancing phosphorus availability in phosphorus-fertilized zones by reducing phosphate adsorbed to ferrihydrite using rice straw-derived biochar. Journal of Soils and Sediments, 11, 1135-1141.

Du, Z., Wang, Y., Huang, J., Lu, N., Liu, X., Lou, Y. \& Zhang, Q. (2014). Consecutive biochar application alters soil enzyme activities in the winter wheat-growing season. Soil Science, 179, 75-83. https://doi. org/10.1097/SS.0000000000000050.

Ferreira, I. Q., Rodrigues, M. A., Moutinho-Pereira, J. M., Correia, C. \& Arrobas, M. (2018). Olive tree response to applied phosphorus in field and pot experiments. Scientia Horticulturae, 234, 236-244. https://doi.org/10.1016/j.scienta.2018.02.050

Gao, S., DeLuca, T. H. \& Cleveland, C. C. (2019). Biochar additions alter phosphorus and nitrogen availability in agricultural ecosystems: A meta-analysis. Science of the Total Environment, 654, 463472. https://doi.org/10.1016/j.scitotenv.2018.11.124

Gilbert, N. (2009). The disappearing nutrient. Nature, 461, 716-718.

Guaya, D., Mendoza, A., Valderrama, C., Farran, A., Sauras-Yera, T. \& Cortina, J. L. (2020). Use of nutrient-enriched zeolite (NEZ) from urban wastewaters in amended soils: Evaluation of plant availability of mineral elements. Science of the Total Environment, 727, 138646. https://doi.org/10.1016/j.scitotenv.2020.138646

Gul, S. \& Whalen, J. K. (2016). Biochemical cycling of nitrogen and phosphorus in biochar amended soils. Soil Biology and Biochemistry, 103, 1-15. https://doi.org/10.1016/j.soilbio.2016.08.001.

Havlin, J. L., Tisdale, S. L., Nelson, W. L. \& Beaton, J. D. (2014). Soil fertility and fertilizers, an introduction to nutrient management, 8th edn. Pearson, .

Jarrel, W. M. \& Beverly, R. B. (1981). The dilution effect in plant nutrition studies. Advances in Agronomy, 34, 197-224.

Jones, J. B.Jr (2001). Laboratory guide for conducting soil tests and plant analysis. CRC Press.

Kavitha, B., Reddy, P. V. L., Kim, B., Lee, S. S., Pandey, S. K. \& Kim, K.-H. (2018). Benefits and limitations of biochar amendment in agricultural soils: A review. Journal of Environmental Management, 227, 146-154. https://doi.org/10.1016/j.jenvman.2018.08.082
Kongshaug, G. (2007). Phosphate fertilizers (Caps 1-4, 13-15). In: Ullmann's Agrochemicals 1, Wiley-VCH, Velag GmbH \& Co. KGaA.

Li, G., Huang, G., Li, H., van Ittersum, M. K., Leffelaar, P. A. \& Zhang, F. (2016). Identifying potential strategies in the key sectors of China's food chain to implement sustainable phosphorus management: A review. Nutrient Cycling in Agroecosystems, 104, 341-359. https://doi.org/10.1007/s10705-015-9736-z.

Liator, M. I., Katz, L. \& Shenker, M. (2017). The influence of compost and zeolite co-addition on the nutrients status and plant growth in intensively cultivated Mediterranean soils. Soil Use and Management, 33, 72-80. https://doi.org/10.1111/sum.12324

Little, T. M. \& Hills, F. J. (1978). Agricultural experimentation: Design and analysis. John Wiley \& Sons Inc, .

Liu, S., Meng, J., Jiang, L., Yang, X., Lan, Y., Cheng, X. \& Chen, W. (2017). Rice husk biochar impacts soil phosphorous availability, phosphatase activities and bacterial community characteristics in three different soil types. Applied Soil Ecology, 116, 12-22. https:// doi.org/10.1016/j.apsoil.2017.03.020.

Luo, L. \& Gu, J. D. (2016). Alteration of extracellular enzyme activity and microbial abundance by biochar addition: Implication for carbon sequestration in subtropical mangrove sediment. Journal of Environmental Management, 182, 29-36. https://doi.org/10.1016/j. jenvman.2016.07.040.

Masto, R. E., Kumar, S., Rout, T. K., Sarkar, P., George, J. \& Ram, L. C. (2013). Biochar from water hyacinth (Eichhornia crassipes) and its impact on soil biological activity. Catena, 111, 64-71.

Meier, U. (2001). Growth stages of mono-and dicotyledonous plants. BBCH Monographs, 2nd ed. Federal Biological Research Centre for Agriculture and Forestry. BBCH Publ, Germany. 158 pp.

Noori, M., Ahmadi, A. \& Zendehdel, M. (2007). Comparative study between using natural and synthetic zeolites for the improvement of soil salinity and crop yield. Toxicological \& Environmental Chemistry, 89, 233-241. https://doi.org/10.1080/02772240601035771

Pickering, H. W., Menzies, N. W. \& Hunter, M. N. (2002). Zeolite/rock phosphate-a novel slow release phosphorus fertiliser for potted plant production. Scientia Horticulturae, 94, 333-343. https://doi. org/10.1016/S0304-4238(02)00006-7.

Prawiyanto, Y., Shofiyani, A. \& Zaharah, T. A. (2018). Synthesis and characterization of zeolite materials from power plant fly ash. Asian Journal of Chemistry, 30, 993-997. https://doi.org/10.14233/ ajchem.2018.21089.

Rodrigues, M. A., Piroli, V. L. B., Forcelini, D., Raimundo, D., Domingues, L. S., Cassol, L. C., Correia, C. M. \& Arrobas, M. (2021). Use of commercial mycorrhizal fungi in stress-free growing conditions of potted olive cuttings. Scientia Horticulturae, 275, 109712. https://doi.org/10.1016/j.scienta.2020.109712

Rodrigues, M. A., Raimundo, S., Pereira, A. \& Arrobas, M. (2020). Large chestnut trees (Castanea sativa) respond poorly to liming and fertilizer application. Journal of Soil Science and Plant Nutrition, 20, 1261-1270.

Ryakhovskaya, N. I. \& Gainatulina, V. V. (2009). Potato and oat yield in short-cycle crop rotation with zeolite application. Russian Agricultural Sciences, 35, 153-155. https://doi.org/10.3103/S1068 367409030069

Shaaban, M., Zwieten, L. V., Bashir, S., Younas, A., Núñez-Delgado, A., Chhajro, M. A., Kubar, K. A., Ali, U., Rana, M. S., Mehmood, M. A. \& Hu, R. (2018). A concise review of biochar application to agricultural soils to improve soil conditions and fight pollution. Journal of Environmental Management, 228, 429-440. https://doi. org/10.1016/j.jenvman.2018.09.006 
Si, L., Xie, Y., Ma, Q. \& Wu, L. (2018). The short-term effects of rice straw biochar, nitrogen and phosphorus fertilizer on rice yield and soil properties in a cold waterlogged paddy field. Sustainability, 10, 537-544. https://doi.org/10.3390/su10020537.

Temminghoff, E. E. J. M. \& Houba, V. G. (2004). Plant analysis procedures, 2nd edn. Kluwer Academic Publishers,

Tian, D., Li, Z., O'Connor, D. \& Shen, Z. (2020). The need to prioritize sustainable phosphate-based fertilizers. Soil Use and Management, 36(3), 351-354. https://doi.org/10.1111/sum.12578

Türk, M., Albayrak, S. \& Yüksel, O. (2007). Effects of phosphorus fertilisation and harvesting stages on forage yield and quality of narbon vetch. New Zealand Journal of Agricultural Research, 50, 457-462. https://doi.org/10.1080/00288230709510313.

Reeuwijk, 2002Van Reeuwijk, L. P. (2002). Procedures for soil analysis. 6th Edn., Technical Paper 9, ISRIC, FAO, Wageningen, The Netherlands.

Wang, L., Ok, Y. S., Tsang, D. C. W., Alessi, D. S., Rinklebe, J., Wang, H., Masek, O., Hou, R., O'Connor, D. \& Hou, D. (2020). New trends in biochar pyrolysis and modification strategies: Feedstock, pyrolysis conditions, sustainability concerns and implications for soil amendment. Soil Use and Management, 36(3), 358-386. https://doi. org/10.1111/sum.12592

Wang, X., Tang, C., Guppy, C. N. \& Sale, P. W. G. (2010). Cotton, wheat and white lupin differ in phosphorus acquisition from sparingly soluble sources. Environmental and Experimental Botany, 69, 267-272. https://doi.org/10.1016/j.envexpbot.2010.04.007.

Watt, M. \& Evans, J. R. (2003). Phosphorus acquisition from soil by white lupin (Lupinus albus L.) and soybean (Glycine max L.), species with contrasting root development. Plant and Soil, 248, 271283. https://doi.org/10.1023/A:1022332700686.

Wei, W., Yang, H., Fan, M., Chen, H., Guo, D., Cao, J. \& Kuzyakov, Y. (2020). Biochar effects on crop yields and nitrogen loss depending on fertilization. Science of the Total Environment, 702, 134423. https://doi.org/10.1016/j.scitotenv.2019.134423
WRB. (2015). World reference base for soil resources 2014, Update 2015. International soil classification system for naming soils and creating legends for soil maps. World Soil Resources Reports No. 106. FAO, Rome.

Xu, G., Zhang, Y., Sun, J. \& Shao, H. (2016). Negative interactive effects between biochar and phosphorus fertilization on phosphorus availability and plant yield in saline sodic soil. Science of the Total Environment, 568, 910-915. https://doi.org/10.1016/j.scito tenv.2016.06.079.

Yu, H., Zou, W., Chen, J., Chen, H., Yu, Z., Huang, J., Tang, H., Wei, X. \& Gao, B. (2019). Biochar amendment improves crop production in problem soils: A review. Journal of Environmental Management, 232, 8-21. https://doi.org/10.1016/j.jenvman.2018.10.117

Zhang, H. Z., Chen, C. R., Gray, E. M., Boyd, S. E., Hong, Y. \& Zhang, D. K. (2016). Roles of biochar in improving phosphorus availability in soils; a phosphate adsorbent and a source of available phosphorus. Geoderma, 276, 1-6. https://doi.org/10.1016/j.geode rma.2016.04.020.

Zheng, M., Huang, J., Chen, H., Wang, H. \& Mo, J. (2015). Responses of soil acid phosphatase and beta-glucosidase to nitrogen and phosphorus addition in two subtropical forests in southern China. European Journal of Soil Biology, 68, 77-84. https://doi.org/10.1016/j. ejsobi.2015.03.010

How to cite this article: Arrobas M, Decker JV, Feix BL, et al. Biochar and zeolites did not improve phosphorus uptake or crop productivity in a field trial performed in an irrigated intensive farming system. Soil Use Manage. 2021;00:1-12. https://doi. org/10.1111/sum.12704 